19 Revue d'histoire du XIXe siècle

Société d'histoire de la révolution de 1848 et des

révolutions du XIXe siècle

18 | 1999

Varia

\title{
Fête publique et citoyenneté. 1848, une tentative de régénération civique par la fête
}

Rémi Dalisson

OpenEdition

Journals

Electronic version

URL: http://journals.openedition.org/rh19/147

DOI: $10.4000 /$ rh19.147

ISSN: 1777-5329

Publisher

La Société de 1848

Printed version

Date of publication: 1 June 1999

ISSN: 1265-1354

Electronic reference

Rémi Dalisson, «Fête publique et citoyenneté. 1848, une tentative de régénération civique par la fête », Revue d'histoire du XIXe siècle [Online], 18 | 1999, Online since 04 September 2008, connection on 21 April 2019. URL : http://journals.openedition.org/rh19/147 ; DOI : 10.4000/rh19.147

This text was automatically generated on 21 April 2019

Tous droits réservés 


\title{
Fête publique et citoyenneté. 1848, une tentative de régénération civique par la fête
}

\author{
Rémi Dalisson
}

\section{ABSTRACTS}

Public fête and citizenship. 1848: an attempt at civic regeneration by the fête The FortyEighters were keen on showing that politics is also a matter of symbols, and from its birth, the Second Republic tried to catch up with the festive tradition of the French Revolution while taking into account the way the July Monarchy had also used this legacy of public fêtes. The author shows that the government immediately tried to give some legitimacy to its civic fêtes. It legislated very fast, with a number of decrees higher than any regime before and after. Celebrations followed a ritual that tried to be very didactic. Even afternoon entertainment following political and religious events tended to mark the break with the monarchic fête: music societies and popular balls witness the egalitarian and collective ideal of February. The success of the fête also varied according to the season and the course of events. How, then, should the way the population greeted and took part in those fêtes be assessed? The local geography of the fêtes, seen here through two départements -those of Seine-et-Marne and of Seine-Inférieure- as well as the number of incidents, show a politicisation of the fête whose ideological stakes were totally understood by the public.

Les hommes de 1848 ont eu à cœur de montrer que la politique est aussi affaire de symboles et dès sa naissance la Seconde République a voulu renouer les fils de l'histoire festive de la Révolution française tout en tenant compte des captations d'héritage réalisées par la Monarchie de Juillet, héritière elle aussi d'une tradition de fêtes publiques. L'auteur montre que le 
gouvernement a immédiatement voulu donner une légitimité à ses fêtes citoyennes. Il a légiféré très rapidement et surpasse par le nombre des décrets tous les régimes précédents et même suivants. Les célébrations obéissent à un rituel qui se veut très didactique. Même les divertissements de l'après midi qui succèdent aux démonstrations religieuses et politiques tendent à souligner la rupture avec la fête monarchique: les sociétés musicales et les bals populaires sont là aussi pour témoigner de l'idéal égalitaire et collectif de février. Le succès de la fête va varier aussi selon la saison et suit le cours des événements. Comment alors percevoir l'accueil et la participation de la population? La géographie locale des fêtes - vue ici à travers deux départements, ceux de la Seine-et-Marne et de la Seine-Inférieure - et la fréquence des incidents traduisent une politisation croissante de la fête qui montre que ses enjeux idéologiques sont tout à fait compris du public.

INDEX

Mots-clés: 1848, Citoyenneté, Fête 